\title{
A docência e seus saberes: o valor do testemunho para o ensino
}

\author{
Teaching and their knowledge: value of testimony for the education
}

La docencia y sus saberes: el valor del testimonio para la enseñanza

MAIANE LIANA HATSCHBACH OURIQUE*

ELIANA REgINA FRITZEN PEDROSO**

$\diamond$

\begin{abstract}
RESUMO
O trabalho busca investigar como o processo formativo da docência percebe os saberes necessários à educação em um século pós-traumático. Tendo em vista a necessidade formativa de compreender de maneira crítica o valor do pertencimento ao mundo e a constituição dessa historicidade, própria do humano, o trabalho evidencia a ideia de saber com sua potência epistêmica, ética e estética. Em uma perspectiva metodológica hermenêutica e reconstrutiva, a investigação repercute a noção de que o saber tem a função de "vincular o homem ao mundo". Por isso, ao evocar a memória e a alteridade para aproximar-se dos acontecimentos, os saberes da docência também são afetados pelos eventos catastróficos e pelas tragédias que cingiram a história da humanidade. Assim, o saber do testemunho passa a constituir uma ponte interessante para uma educação que valoriza a pluralidade a partir da conciliação entre o passado e o presente.
\end{abstract}

Palavras-chave: Docência. Saberes. Formação. Testemunho. Pós-traumático.

\begin{abstract}
This paper investigates how the formation process of teaching perceives the knowledge necessary for education in a post-traumatic century. In view that the formative need to understand critically the value of belonging to the world and the constitution of this human historicity, this work enphasizes the idea of knowing with its potentials epistemic, ethics and aesthetics. This research too reflected the notion that knowledge has the function to "bind man at the world". That is why to evoke the memory and otherness to approach the events, the knowledges teaching are alsoaffected by catastrophic events and tragedies that comprehended the humanity history. Thus, knowledge of the testimony shall be an interesting bridge to an education that values the plurality from the reconciliation between the past and the present.
\end{abstract}

Keywords: Teaching. Knowledge. Training. Testimony. Post-traumatic.

\section{RESUMEN}

El trabajo tiene como objetivo investigar cómo el proceso de formación de la docencia percibe los saberes necesarios para la educación en un siglo post-traumático. Dada la necesidad formativa de entender críticamente el valor de pertenencia al mundo y la constitución de esta historicidad, propia del humano, el trabajo subraya la idea de saber con suya potencia epistémica, ética y estética. En una perspectiva metodológica hermenéutica y reconstructiva, la investigación refleja la idea de que el saber tiene la función de "articular el hombre al mundo". Por lo tanto, al evocar la memoria y la alteridad para acercarse de los conocimientos, los saberes de los maestros también se ven afectados por los factos catastróficos y trágicos que envolverán la historia de la humanidad. Es decir, el saber del testimonio ha constituido un puente interesante a una educación que valora la pluralidad a partir de la conciliación entre el pasado y el presente.

Palavras clave: Docencia. Saberes. Formación. Testimonio. Post-traumático.

\footnotetext{
*Doutora em Educação, professora adjunta da Universidade Federal do Pampa, Câmpus Jaguarão, RS/Brasil. E-mail: <maianeho@yahoo.com.br>.

**Mestra em Educação, licenciada em Pedagogia e professora no município de Santa Maria/RS/Brasil. E-mail: <eliana.fritzen@yahoo.com.br>.
} 


\section{CONSIDERAÇÕES INICIAIS}

Buscou-se discutir, neste trabalho, algumas questões vinculadas à vivência em um século pós-traumático e à valorização da memória e da historicidade próprias do ser humano, como características que podem se relacionar com o saber produzido na formação de docentes. Tomou-se como principal problemática os saberes pautados exclusivamente por um viés cognitivo que reverberam atualmente nas pesquisas sobre formação docente e compõem uma epistemologia própria no campo da educação. O professor possui uma tarefa complexa, que envolve não apenas aspectos acadêmicos e pedagógicos, mas também ético-estéticos, responsáveis pela atribuição de sentido aos conceitos ensinados em aula. Nesse sentido, a cognição se apresenta como um dos fatores da produção do conhecimento. Somado a ele, o sujeito lança mão da memória, de experiências passadas, de ensinamentos culturais, do senso estético, da intuição, entre outros.

Em contraponto, é corrente no cotidiano a banalização de diferentes tipos de violência, de desrespeito ou de indiferença com o outro, que surpreendem as expectativas de vida e sobrevivência. O descaso com o humano manifesta-se também dentro dos ambientes de formação, sejam escolas ou universidades. Esses acontecimentos atingem tanto professores quanto alunos, alimentando barbáries ${ }^{1}$ e/ou gerando traumas, difíceis de serem entendidos/resolvidos. Os exemplos vão desde situações já comuns de alunos levarem armas para a sala de aula até crianças na escola com marcas visíveis de violência, aguentando, impotentes, a indiferença da família e da sociedade. Ainda, a cada início de ano letivo, os meios de comunicação chamam a atenção para relatos de alunos que foram torturados pelos veteranos nos chamados "trotes" universitários. Essas situações, dentre tantas outras, são apenas exemplos de relações desumanas em espaços onde se deveria, justamente, promover a humanização. De algum modo, tais exemplos alertam para os efeitos de barbárie que toda sociedade está sujeita: "O efeito de barbárie caracteriza toda forma de esterilidade humana e de perda do sentido no campo da cultura, quer se trate de ética, de política, de arte, quer de educação" (MATTÉI, 2002, p. 13).

Assim, quando a razão é instrumentalizada e passa a controlaras ações e formas de vida, corre-se o risco de se alimentarmos a barbárie do cotidiano, manifestada como brutalidade, indiferença ou esquecimento para com o outro. Para Paul Ricoeur (2007), uma das definições de esquecimento é o apagamento dos rastros da memória. Essa perda da memória contribui para o rompimento com a historicidade dos acontecimentos e com seu significado como produção cultural, fortalecendo, na atualidade, o apoio a movimentos antidemocráticos, racistas, xenofóbicos ou homofóbicos, por exemplo. Essas situações põem em cheque narrativas importantes à sociedade ocidental (democracia, liberdade, igualdade de direitos, autonomia, entre outras), replicando impulsos (auto)destrutivos e restringindo a temporalidade ao presente.

Autores como Eric Hobsbawm (1995) caracterizam o século XX como "era das catástrofes" ${ }^{2}$ justamente por esse período ser marcado por muitas guerras e mortes em massa. Naquele tempo, também houve um extraordinário avanço tecnológico, que permitiu o aprimoramento de material bélico e de expansão de domínios por via de grandes batalhas. Segundo Shoshana Felman (2000), vive-se em um século pós-traumático, isto é, barbáries impensáveis ocorreram, promovendo uma cisão na história da humanidade, e hoje pode-se pensar se algo foi aprendido com tudo isso. Referindo-se ao indivíduo, o processo pós-traumático é um distúrbio da ansiedade vivido a cada vez que ele se lembra do episódio traumático em que foi vítima ou testemunha. Essa reminiscência provoca sintomas físicos, psíquicos e emocionais, semelhantes à barbárie vivida naquele episódio. Lidar e compreender esses fatos exige a composição de muitas relações entre passado e presente, identidade e alteridade, subjetividade e cultura. O processo de formação humana configura-se através dessas tessituras feitas entre as vivências - do indivíduo - e as experiências ${ }^{3}$ que abrangem o campo intersubjetivo. Isto é, envolvem a compreensão dos

\footnotetext{
Se, à primeira vista, a ideia de barbárie remete ao tempo antigo - da separação entre civilização romana e povos bárbaros -, uma compreensão mais profunda aponta não apenas para grandes eventos de violência, genocídios ou massacres, mas também para a agressividade que reside no interior do humano. O que fragiliza a noção de conquista da modernidade e abre caminho para o surgimento de novas barbáries. Nessa perspectiva, a lógica operada não é metafísica, que define um dos polos em função do outro, mas pós-metafísica, compreensível pela linguagem e em sua historicidade. Jean-François Mattéi (2002, p. 12) lembra grandes pensadores que já se dedicaram ao tema - Goethe, Schiller, Adorno, Castoriadis - para enfatizar que "a barbárie não remete a uma invasão da violência que viria do exterior revirar nossa intimidade, e sim a essa própria intimidade a partir do momento em que ela se apresenta como autônoma e arrogante". Dessa forma, Mattéi (2002, p. 12-13) junta-se a esses estudos, entendendo por barbárie "o colapso do humano e sua regressão a uma violência despida de significado; é no interior do homem que precisamos detectar as tendências a cair na barbárie".

2 Já no sentido etimológico da palavra catástrofe (do grego kata + strophé), que significa "virada para baixo", é possível compreender o grande impacto que os eventos catastróficos tendem a produzir, gerando grandes transformações no contexto natural ou humano.

3 Considera-se, neste trabalho, a ideia de experiência apontada por Walter Benjamin, não limitada a uma ação na realidade, mas estabelecendo uma compreensão dessas vivências ao perceber as potencialidades das narrativas da tradição. Observando os rumos da tecnificação e o impacto da força produtiva da guerra, Benjamin (1986, p. 115) afirma: "Uma nova forma de miséria surgiu com esse monstruoso desenvolvimento da técnica, sobrepondo-se ao homem". Ele estava se referindo à efervescência, nos últimos tempos, de múltiplas formas de perceber e explicar o mundo, que não mantinham um compromisso com o pensamento clássico e com sua historicidade, como a renovação da astrologia ou da ioga, da escolástica e do espiritismo.
} 
acontecimentos, tendo em vista sua historicidade e as possibilidades de memória e alteridade. Por isso, nesse século caracterizado como pós-traumático, retoma-se a ponderação de Valéria De Marco (2004, p. 59): "Se a vivência dos campos coube a alguns milhões de pessoas, a experiência do aniquilamento do outro racionalmente administrado é herança para todos nós".

Ainda se tem contato com gerações de sobreviventes às grandes guerras, testemunhas do que a total desconsideração ao pensamento "não idêntico" é capaz de produzir. Vive-se, segundo Felman (2000), uma "era do testemunho", caracterizada por uma gama de registros na literatura, nos filmes e na arte de modo geral. Essas produções têm sido o meio de transmissão mais palpável de vivências que envolvem barbáries coletivas e traumas, cujo esquecimento seria o meio mais rápido e menos pedagógico de se livrar de atos cometidos contra a humanidade. A partir desse cenário, pergunta-se de que forma a compreensão das tragédias humanas pode interferir nas concepções sobre os saberes da docência? A intenção deste estudo é, pois, investigar como o processo formativo da docência percebe os saberes necessários à educação em um século pós-traumático.

Acontecimentos de maior abrangência, tais como os campos de concentração, a fome mundial, a valorização do capital, ou episódios próximos, como a tragédia ocorrida na Boate Kiss (Santa Maria/RS/BR), a miséria dos salários dos professores e as improvisadas construções de lata (usadas como escolas no Brasil), em algum sentido, mobilizam a construção do conhecimento. Esses fatos perfazem os aspectos ético-estéticos da ideia de saber, referidos inicialmente, corroborando tanto para indagar sobre qual é o papel da educação e da docência quanto para colocar em cheque a própria existência da escola - caso esta trate de tais fatos apenas como elementos históricos, passados.

Para compreender essas inter-relações, buscouse seguir um enfoque hermenêutico, que defende uma rememoração do passado, por meio da ação compreensiva para prover lições ao contemporâneo. Em vista dessa possibilidade de compreensão, a hermenêutica recorre à história efetual para destacar as principais transformações históricas dos conceitos pautados em um determinado contexto. Para Hans-Georg Gadamer, o próprio processo de compreender demanda que se analise sua implicação histórico-epistemológica, que compõe o círculo hermenêutico entre o todo e a parte. Isso pode ser esboçado na inter-relação do pesquisador com o texto, assim como com os outros sujeitos. Conforme aduz o filósofo, "[...] vemos confirmado que compreender significa, primariamente, sentir-se entendido na coisa, e somente secundariamente destacar e compreender a opinião do outro como tal" (GADAMER, 1997, p. 441).
A partir desse entendimento, a hermenêutica reconstrutiva, desenvolvida por Jürgen Habermas, vê como necessário integrar ao processo de compreensão uma dimensão que envolve a reflexão e a crítica, agregando as influências da dialética, num processo interativo que é essencialmente linguístico:

A prontidão hermenêutica para a compreensão mútua de outras culturas e formas de vida e a aprendizagem recíproca entre estrangeiros nos levam a corrigir nossas prevenções. [...] A ausência de uma análise convincente da função representativa da linguagem, e portanto das condições de referência e verdade dos enunciados, permanece sendo o calcanhar de Aquiles de toda a tradição hermenêutica (HABERMAS, 2004, p. 74).

É por isso que a hermenêutica reconstrutiva não interpreta a realidade explorando a dimensão compreensiva apenas, mas, sim, considerando as interações comunicativas que buscam um consenso para se distanciar das aporias da razão instrumental ${ }^{4}$. O processo reconstrutivo pode ser explorado no terreno epistemológico que envolve o saber, por meio da forma discursiva que relaciona o indivíduo ao mundo. Assim, o movimento da cultura é exercido para incorporar o diferente. Nesse sentido, o processo formativo da docência pode agregar saberes que levem em conta a historicidade particular e coletiva como forma de exercitar a alteridade. Encontram-se muitos desses elementos na chamada literatura de testemunho, a qual visa a dar voz ao outro, subsumido, muitas vezes, dentro da história contada pelos vencedores.

\section{OS SABERES DA FORMAÇÃO E SUAS DIFERENTES RACIONALIDADES}

Vive-se em um tempo em que as barbáries decorrem muito mais do descaso para com o humano do que de cataclismos ou eventos acidentais. Para Jean-François

\footnotetext{
4 Para Habermas, a racionalidade possui uma face instrumental e uma face comunicativa. A primeira sustenta as ações do mundo sistêmico (instituições, autarquias, etc.); a segunda inscreve as possibilidades de a razão criticar a si mesma. Tentando apontar outros caminhos para a crítica feita por Adorno e Horkheimer sobre a mitificação da própria razão, desenvolvida apenas em seu sentido instrumental, Habermas (2001, p. 180-181) expõe a radicalidade do sentido da concepção adorniana de dialética negativa: "A dialética hegeliana do Esclarecimento teve sua ponta quebrada. Pior ainda, à medida que a racionalidade instrumental incha e torna-se um todo irracional, a crítica do todo falso enreda-se em uma aporia. Assim que a crítica da razão instrumental não pode mais ser realizada em nome da razão, ela - e com ela a crítica da modernidade - perde um fundamento normativo próprio. Adorno fez da dificuldade aporética - a qual é tornada consciente na execução da crítica autorreferencial - a virtude da dialética negativa. Ele permaneceu fiel ao empreendimento de uma crítica declaradamente paradoxal e "sem chão", à medida que desmentiu exatamente as condições que deveriam ser preenchidas para que fosse possível a operação da crítica realizada in actu.
} 
Mattéi (2002), a questão da barbárie no contemporâneo se estrutura a partir dos opostos: exterior e interior, paralelamente ao que se poderia entender como sociedade e subjetividade. Sua teoria afirma que há uma barbárie que assola a sociedade e também o sujeito conforme sua constituição moderna. A barbárie interior tem sua origem no não reconhecimento do que está no exterior, isto é, nos próprios fundamentos da civilização: religião, natureza, cultura. Dessa forma, parece que os alicerces civilizatórios constituem-se apenas por um princípio de interiorização. E esta não olha para o outro, para o diferente, para o que está fora, mas, sim, para o que está no interior: o mesmo, o sempre igual, o homogêneo.

$\mathrm{O}$ aspecto que sobressai na composição do homem moderno é sua subjetividade, as características individuais que o fazem ser o que é. $\mathrm{Na}$ sociedade capitalista contemporânea, isso está evidente nos processos de individuação, pois os objetos de consumo permitem, de certa forma, ao sujeito ser único. A autoprodução metafísica do sujeito moderno, segundo Mattéi, nega os fundamentos da civilização, radicalizando a singularidade do humano e cultivando aquilo que Marx já havia apontado em seus escritos: "A raiz para o homem é o próprio homem". Questionando essa postura solipsista, Mattéi tenta mostrar que o princípio de humanidade não se constrói sobre uma subjetividade petrificada, pois "se o sujeito é apenas um sujeito factício, privado de todo recurso substancial, ele corre o risco de permanecer sujeitado a si mesmo e de se petrificar, assim, diante de seu próprio espelho em puro objeto de representação" (MATTÉI, 2002, p. 26). É na base da autoconstrução metafísica do sujeito, quando se desliga das instâncias da civilização em nome de si mesmo, e do seu reflexo de igual, que se torna mais facilmente objeto de dominação. De outro modo, o autor tenta mostrar que o sujeito, cuja formação se dá mais firmemente por meio do estabelecimento de vínculos com a cultura, não está tão suscetível a corroborar com a barbárie:

Se a barbárie pode acompanhar todo documento de civilização, segundo a célebre fórmula de Benjamin, é porque ela está presente, em seu excesso, no coração do movimento que atormenta internamente a civilização, assim como atormenta cada homem, mesmo esclarecido pelas luzes do seu tempo (MATTÉI, 2002, p. 21).

Podem ser exemplos de barbárie gerada pelo descaso com o humano a tragédia ocorrida em janeiro de 2013, em Santa Maria/RS; os inúmeros casos de assassinatos, friamente premeditados de pais contra filhos ou de filhos contra pais; o mau uso do dinheiro público no recente caso de corrupção do chamado "Mensalão"; as discussões e tentativas no Congresso Nacional de abafar manifestações homofóbicas dos próprios deputados e senadores.
Diante desses eventos, pode-se questionar sobre o papel da educação na compreensão dessas tragédias e na prevenção a novas. Ainda sobre a forma que o professor pode lidar com esse processo. E sobre quais saberes constituir ou reconfigurar para que as barbáries percam força diante da visibilidade do humano.

A seguir, centraliza-se a discussão nas racionalidades que o termo saber pode abrigar, de modo a repercutir suas condições de possibilidade na elaboração da experiência do professor. Na discussão sobre o processo formativo da docência, algumas formas do conceito de saber ainda não são suficientemente tratadas. Diferentemente da acepção de saber-fazer, que reverbera na formação docente, tendo, inclusive, uma epistemologia própria no campo da educação.

As orientações legais para a formação de professores (Lei de Diretrizes e Bases da Educação Nacional 9.394/96 e Diretrizes Curriculares Nacionais de Formação de Professores para a Educação Básica - Parecer CNE/CP 09/2001 e Resolução CNE/CP 01, de 02/2002), por exemplo, indicam uma formação baseada na constituição de competências e habilidades práticas, que o sujeito pode utilizar em situações que exijam uma ação eficaz. Nesse sentido, a competência é vista como um resultado estritamente cognitivo, que o docente deve apresentar ao final de sua formação. Significa, segundo Perrenoud, "um lugar importante concebido aos saberes da e sobre a prática, para equilibrar o peso dos saberes a serem ensinados ou dos saberes eruditos descontextualizados" (2002, p. 20).

Essa perspectiva pode ser entendida como epistemologia da prática, conforme define Maurice Tardif (2002, p. 255): "Chamamos de epistemologia da prática profissional o estudo do conjunto dos saberes utilizados realmente pelos profissionais em seu espaço de trabalho cotidiano para desempenhar todas as suas tarefas". Dessa forma, a noção de saber adquire "um sentido amplo, que engloba os conhecimentos, as competências, as habilidades (ou aptidões) e as atitudes, isto é, aquilo que muitas vezes foi chamado de saber, saber-fazer, e saber-ser" (ibid.).

No que concerne a uma discussão mais ampla sobre a categoria do "saber", Luiz Carlos Bombassaro (1992) busca considerar a historicidade e a racionalidade como categorias que estão na fronteira do pensamento epistemológico, cuja relação entre ambas pode ser articulada por meio da hermenêutica. Ponderando sobre o conhecimento como um objeto de investigação, Bombassaro apresenta os horizontes de distinção entre o "saber" e o "conhecer". Sua ideia é a de fundamentar o termo "saber" como um conceito epistêmico. Esse autor denota dois modos que o sentido de "saber" adquire da história da filosofia à filosofia da linguagem. Um destes é 
retirado da filosofia platônica, inspirada, por sua vez, na teoria de Parmênides, referindo-se ao saber como uma opinião verdadeira, alicerçada em um processo reflexivo. Surge daí a distinção entre saber (episteme) e opinião $($ doxa $)$. Essa compreensão é semelhante em Kant, que retrata a insuficiência da opinião, diante da verdade, pois não é construída com base em argumentos válidos e, portanto, não apresenta correspondência entre sujeito e objeto.

Esse é o sentido clássico de "saber", diferenciado da opinião, porque seria mais refinado do que esta, cuja fundamentação está unicamente no plano subjetivo. O saber dialoga com a realidade e é tecido nas concepções subjetivas e objetivas, dispondo das narrativas necessárias para unir não só a dimensão racional do ser humano, mas também a dimensão histórico-cultural.

Ainda no âmbito do primeiro modo de referência ao saber, porém desenvolvido de acordo com a filosofia da linguagem, Bombassaro expõe a proposta de Gilbert Ryle, apresentando os usos linguísticos do verbo saber, o "saber que" e o "saber fazer". Desse modo, o "saber que" exige um segmento frasal para determinar "o que se sabe", por exemplo, sabemos que a condição das escolas públicas brasileiras é precária. Por isso, "o sentido do 'saber que' revela uma forma de saber chamada 'proposicional', pois seu conteúdo é sempre expresso por uma proposição que pode ser verdadeira ou falsa" (BOMBASSARO, 1992, p. 20). O teor de validade dessa forma de saber é associado à justificativa de expressar a crença em algo, e a partir disso direcionar uma ação.

Quanto ao uso do termo saber que direciona uma ação ou como "saber fazer" pode ser compreendido pelo uso da palavra "saber" adicionada a um verbo no infinitivo. Dessa forma, não está em pauta um processo de validade, mas, sim, a exigência de uma convicção prévia em uma habilidade para ser dinamizada em ações complexas, como, por exemplo, "saber fazer", "saber ouvir". Contudo, esse tipo de saber não engloba todas as possibilidades epistemológicas do termo, restringindo-se a um exercício que busca um fim.

Esses três sentidos de saber - o saber clássico, o 'saber que' e o 'saber fazer' - conjecturam, segundo Bombassaro, o primeiro sentido atribuído ao termo, enquanto "crença no saber". Para saber algo, é preciso crer que essa concepção seja verdadeira: "Embora não se possa dizer que todo crer implica saber, a primeira condição para saber é crer" (BOMBASSARO, 1992, p. 21). A ideia de saber como crença está associada a uma dimensão normativa do termo, responsável pelos critérios que se elegem para acreditar e, partir disso, elaborar as concepções teóricas sobre o mundo.

O segundo modo de entendimento de saber está, de certa forma, ligado ao aspecto pragmático da "crença em algo", impressa na noção de "poder". Indo além da aquisição normativa do saber, o indivíduo que "sabe", nessa concepção, também "pode". Quando se sabe, pode-se mobilizar instrumentos que permitam a 'compreensão de', 'a capacidade de'. Essas pré-disposições, em alguma medida, influenciam a caracterização da apreensão da realidade pelo indivíduo. Assim, "a investigação do saber como conceito epistêmico remete ao prático, pois o saber revela-se em instância que vincula o homem ao mundo" (BOMBASSARO, 1992, p. 21).

Se o saber é responsável pela vinculação do homem ao mundo e à educação, pela relação desse homem com o conhecimento sobre os objetos produzidos culturalmente pela humanidade, pode-se pensar sobre os saberes presentes no campo da educação. E mais, sobre a forma como esse saber da experiência humana é considerado no processo formativo do professor. Levanta-se aqui a hipótese de que o sentido da experiência docente não estaria seguramente pautado em sua responsabilidade de promover a vinculação do homem com sua historicidade se deixasse de abordar os eventos negativos, que cingiram a história da humanidade e fortaleceram apenas a dimensão instrumental da razão.

\section{O SABER DO TESTEMUNHO EM TEMPOS PÓS-TRAUMÁTICOS}

Considerando que a educação tem uma tarefa que vai além da instrução ou do repasse dos conhecimentos acumulados, atingindo o campo da formação humana, seu compromisso em tratar as barbáries vividas pelo homem é imanente. A compreensão desses fatos exige muito mais do que um mapeamento histórico de suas causas e consequências, envolve também um olhar reconstrutivo e crítico sobre os valores e formas de vida da sociedade.

Para a composição desse cenário compreensivo, entende-se que a docência está diante de um saber de outra ordem, ancorado nas possibilidades oferecidas pela experiência e pela linguagem, ou seja, aportado na dimensão estética da formação:

A experiência estética mostra também que uma orientação ética meramente abstrata e reflexiva, sem a experiência sensorial, perde algo, justamente aquilo que só podemos experimentar na indeterminabilidade da aparência. Ou seja, ela abre espaço para relativizar o domínio do racional, os exageros de erigir a formação, desprezando a contribuição da fantasia, do erotismo, das emoções (HERMANN, 2010, p. 46).

Os recursos da sensibilidade colocam o sujeito diante da radical pluralidade de sentidos, instigando-o a buscar outras formas de compreender o cotidiano e a cultura, para além dos conceitos usualmente utilizados. Criam, 
inclusive, possibilidades de desconstruir estereótipos e preconceitos que vulgarizam as relações cotidianas e deformam seu processo formativo. Para Adorno, o campo da estética é especialmente exigido após Auschwitz, precisando distanciar-se da contemplação do belo para denunciar a realidade. Depois das atrocidades cometidas na Segunda Grande Guerra, as palavras não são suficientes para expressar aquelas experiências, o que somente a experiência estética pode ensinar:

A afirmativa de que após Auschwitz não é mais possível escrever poesia, não deve ser cegamente interpretada, mas com certeza depois que Auschwitz se fez possível e que permanece possível no futuro previsível, a alegria despreocupada na arte não é mais concebível (ADORNO, 2001, p. 16).

A arte potencializa a distinção entre o real e o aparente ao desestabilizar as formas cotidianas de pensar e agir e apresentar outras perspectivas de entendimento, denunciando, se for o caso, as barbáries ocorridas em nosso tempo: "A arte somente pode revestir-se de um sentido na negação do mundo presente. Auschwitz e a Shoah demonstraram, na opinião de Adorno, a inanidade da cultura ocidental, imponente para prevenir o inominável e incapaz de remediá-lo" (JIMENEZ, 1999, p. 358). Assim, a experiência estética está intimamente ligada a uma dimensão ética, pois mantém a necessidade de olhar para o passado no sentido de aprender com seus acontecimentos, principalmente ao promover um estranhamento sobre o modo como se posiciona diante deles. Essa dimensão ético-estética da experiência é considerada por Larrosa (2002, p. 27) da seguinte forma:

Se a experiência é o que nos acontece e se o saber da experiência tem a ver com a elaboração do sentido ou do sem-sentido do que nos acontece, trata-se de um saber finito, ligado à existência de um indivíduo ou de uma comunidade humana particular; ou, de um modo ainda mais explícito, trata-se de um saber que revela ao homem concreto e singular, entendido individual ou coletivamente, o sentido ou o sem-sentido de sua própria existência, de sua própria finitude. Por isso, o saber da experiência é um saber particular, subjetivo, relativo, contingente, pessoal. Se a experiência não é o que acontece, mas o que nos acontece, duas pessoas, ainda que enfrentem o mesmo acontecimento, não fazem a mesma experiência (LARROSA, 2002, p. 27).

Considerando as ponderações de Larrosa, é possível afirmar que o saber mobilizado pelo professor diante da barbárie não passa tanto pela cognição e conscientização, como pelo exercício de pertencimento, (re)elaboração e prevenção, provocando a memória e a alteridade. Nessa configuração, ensinar não requer apenas habilidades cognitivas, mas intersubjetivas, performativas, ou seja, demanda sensibilidade para submeter a experiência pedagógica ao crivo do processo de formação cultural. Para Hermann (2010, p. 34), "a visibilidade de determinados problemas da condição humana só se torna possível pela abertura do jogo da aparência que a experiência estética proporciona, naquilo que é percebido no acontecimento do mundo, num momento único de seu acontecer".

Por viver em um século pós-traumático, o indivíduo é "sobrevivente" e, por vezes, testemunha das viradas que marcaram a história. O termo testemunha (em alemão, ereignis, derivado de ir-ougen, que significa, etimologicamente "por diante dos olhos", mostrar) envolve não somente o ato de assistir, mas de depor sobre o evento que observou. $\mathrm{Na}$ arte, há muitas produções que ampararam relatos dolorosos e traumáticos, registrando essas formas únicas e pesadas de vivenciar as tragédias humanas: "testemunhar (bear witness) é aguentar (bear) a solidão de uma responsabilidade e aguentar (bear) a responsabilidade, precisamente, desta solidão" (FELMAN, 2000, p. 15). Do ponto de vista da testemunha, sua rememoração pode significar, conforme Felman, uma transgressão dos limites de sua isolada posição, muito embora sua expressão seja uma necessidade pessoal, singular, não substituível pelo testemunho de outros. Nesse caminho, Felman aponta três tipos de testemunho, que confluem com o objetivo do sobrevivente em testemunhar: ele pode ser para manter um registro histórico, para promover a cura por meio da fala ou representação ou para servir como instrumento de elaboração do passado por meio da experiência estética. Este último sentido do testemunho é assinalado por Arendt (2007, p. 252) ao caracterizar a crise da sociedade e da cultura de massa, apontando para o artista como "o autêntico produtor daqueles objetos que toda civilização deixa atrás de si como a quintessência e o testemunho duradouro do espírito que a animou".

Sendo assim, é possível aproximar o testemunho expresso na arte com os testemunhos individuais de eventos sociais. Ambos referem-se à possibilidade de produção (tradução ou compreensão) do passado que a experiência estética resguarda na dimensão do sensível, através de imagens, sons, movimentos e outras sensações. Esses elementos testemunham um acontecimento ou relação com o mundo, compondo um saber capaz de (re)construir vínculos culturais e compromissos de reconhecimento do outro. Narrativas que ainda são pouco experienciadas - no sentido benjaminiano, da produção de sentido ao vivido - na formação de professores para além de sua dimensão informativa ou ilustrativa. Dessa forma, entende-se que os testemunhos de Primo Levi, Anne Frank ou dos sobreviventes do Holocausto, por exemplo, podem mobilizar mais do que sensibilidade ou compaixão. Isso porque, concomitantemente, sinalizam a responsabilidade 
que se tem sobre a historicidade e sobre a trajetória humana. No contexto da formação de professores, ainda, provocam que se pense sobre os compromissos culturais e históricos da profissão. E, consequentemente, sobre as formas de narrar os acontecimentos e os enfoques dados, enfatizando a história dos vencidos ou dos vencedores; as concepções políticas das teorias ou sua factualidade; as ordens democráticas de governo ou sua falibilidade. Certamente, todas essas posturas docentes, dentre outras, podem construir ou fortalecer manifestações de esquecimento ou de valorização do humano e de sua trajetória no mundo.

Do ponto de vista de quem toma conhecimento desse testemunho, pode ser uma oportunidade de aproximação com eventos não vividos presencialmente, mas cujas consequências são sentidas de alguma forma. Nas palavras de Felman (ibid., p. 18):

Como uma forma de relação com os eventos, o testemunho parece ser composto de pequenas partes de memória que foram oprimidas pelas ocorrências que não tinham se assentado como compreensão ou lembrança, atos que não podem ser construídos como saber nem assimilados à plena cognição, eventos em excesso em relação aos nossos quadros referenciais.

Os relatos de cunho testemunhal, por exemplo, são elementos importantes para a compreensão das opressões de nosso tempo, tratando da memória como um necessário movimento de alteridade entre os homens para que se tornem mais humanos. A literatura de testemunho ${ }^{5}$ se constitui por meio da troca de relatos discursivos decorrentes da sobrevivência de uma situação traumática. Eles podem envolver um outro viés à prática pedagógica, denominada por Felman como um "ensino testemunhal", através da utilização das diferentes formas de testemunho, promovendo o ensino em uma perspectiva transdisciplinar. Já que o testemunho é capaz de vincular aspectos históricos, culturais, estéticos e linguísticos. Assim, ao mesmo tempo em que se caracteriza por um tipo de narrativa, também é impregnada de aspectos históricos, clínicos, éticos e estéticos que constituem o processo de testemunhar. Por não ter a pretensão de julgamento ou de averiguação - uma vez que não se pauta por uma racionalidade representacional ou cognitivista, mas ético-estética -, toca em aspectos que o viés teórico não dá conta, pois expõe fatos que excedem qualquer conhecimento já elaborado, produzindo impacto, repulsa, emudecimento, perplexidade, estranheza, etc.

A produção da experiência a partir das histórias narradas assemelha-se a um tipo de "saber" encontrado nos romances de formação (Bildungsroman). Isso caracteriza o que se denomina aqui de "saber do testemunho", isto é, a substância viva da experiência tecida na linguagem que, ao ser narrada a outrem, produz um sentido de pertencimento histórico e cultural com a vida humana.
Essa sabedoria, ao ser expressa, apontará no sentido de que as barbáries não tornem a ocorrer. Assim, ao buscar significado pela experiência, Felman lança um desafio: "Será que educadores poderiam ser edificados pela prática do testemunho, enquanto buscam enriquecê-lo e repensá-lo por meio de algumas impressionantes lições literárias?" (2000, p. 14).

Diferentemente de promover uma formação fatalista, a mobilização do saber do testemunho significa fortalecer os laços de professores e alunos com o mundo, cuja historicidade não se constitui apenas pela narrativa da ciência ou do progresso, mas também pelo Holocausto, pela bomba atômica, pelas guerras que aniquilam vidas e culturas. Não é possível, pois, tratar essas barbáries apenas como exemplos ilustrativos de uma época. Elas exigem uma compreensão hermenêutica e reconstrutiva, capaz de debater com profundidade concepções e valores que deixaram o horror e a burocratização da vida se arraigarem. Nessa perspectiva, o saber do testemunho impõe a reflexão sobre o que é vital nas relações. Em última instância, este é, segundo Felman (2000, p. 67), o papel do ensino, ou seja, provocar uma crise: "Se o ensinar não se depara com uma espécie de crise, se ele não encontra nem a vulnerabilidade nem a explosividade de uma dimensão crítica e imprevisível (explícita ou implícita), ele provavelmente não ensinou verdadeiramente".

O saber do testemunho não depende apenas da evocação de relatos ou da bem-sucedida instrumentalização do aluno sobre os fatos acontecidos, ou seja, não está ancorado apenas na instância da subjetividade. Implica "fazer algo acontecer", em um certo "testemunhar", que abrange o âmbito intersubjetivo. Em se tratando da docência, o contato ou a disponibilização de relatos testemunhais sobre as tragédias e traumas que acometem o tempo em que se vive denota uma preocupação do professor com o mundo que precisa ser ampliada. Sua intenção pedagógica - o que ele quer que aconteça - de compreender os valores éticos e estéticos desses fatos para que não voltem a ocorrer pode ser expressa no processo de atribuição de sentido aos relatos, e isso só pode ser feito na/pela linguagem. Essa expressividade ${ }^{6}$ com relação aos

\footnotetext{
5 Há produções marcantes no gênero literatura de testemunho que tematizam acontecimentos da Segunda Guerra Mundial, isto é, experiências vividas nos campos de concentração nazistas, que abrigavam judeus, ciganos, homossexuais, protestantes, negros e inimigos políticos. Dentre outros exemplos, podem-se citar as obras de Primo Levi (1988; 1990; 1997), Paul Celan (1996; 2004), Shlomo Venezia (2010), Jean Améry (2013), Chil Rajchman (2010), Eva Schloss (2013).

${ }^{6}$ A noção do saber-expressar é explicitada de forma ampliada por Pagni (2010, p. 19), afirmando que "significa abordar a razão em sua multiplicidade e em seus diversos instrumentos, os quais concorrem para a constituição de seus gêneros linguísticos, em busca de encontrar os limites e as possibilidades de a experiência se expressar, em sua relação ontológica com a vida e com a estética da existência". Ao buscar o sentido da experiência, o saberexpressar contribui no processo de elaboração do passado e na prevenção a novas tragédias, pois agrega cognição e sensibilidade para localizar a memória e aquilo que ela pode ensinar para o tempo presente.
} 
testemunhos da barbárie revigora o aspecto pragmático do saber, pois expõe aquilo que motiva o homem a produzir conhecimentos, justificando as ações pedagógicas como atitudes de responsabilização com o mundo e com a cultura. Ao contrário disso, um envolvimento superficial ou desinteressado com o passado seria o mesmo que prestar um "falso testemunho".

A figura do professor como testemunha da própria aprendizagem é apresentada por Boufleuer (2007, p. 10) da seguinte forma:

Já um outro estilo de atuação pedagógica é aquele em que a docência é entendida como testemunho da própria aprendizagem e em que o conhecimento é visto como necessariamente baseado em sujeitos que lhe dão suporte, que lhe conferem sentido. Testemunho é aquilo que "se dá" sem se ter o controle sobre seus efeitos junto aos interlocutores. Nesse estilo o professor assume a perspectiva de uma comunicação que opera em termos de construção de aprendizagens exatamente por sua opacidade. Aqui o professor assume o pressuposto de que nós humanos não conseguimos aprender "de" alguém, mas certamente podemos aprender "por causa" de alguém. Tratase, no entanto, de uma "causação" que depende totalmente de nós mesmos, de nossa cumplicidade em aprender.

Ao fazer dos testemunhos da barbárie uma forma de promover o pertencimento dos sujeitos ao mundo, o professor também compartilha com todos a responsabilidade por conhecer este mundo. Isso porque testemunhar ou oferecer testemunhos não significa apontar uma moral, enumerar fatos ou conscientizar o outro, mas personificar o trágico, buscar pequenas partes de memória, sabendo do risco de que esses fragmentos possam não ser compreendidos de forma crítica:

De fato, eu sugeriria mesmo que tanto o mistério quanto a complexidade da tentativa do testemunho e de seu poder compelidor deriva precisamente desse elemento de imprevisibilidade, daquilo que é imprevisível, mais especificamente, dos efeitos da troca e do grau de interação entre as dimensões histórica, clínica e poética do testemunho (FELMAN, 2000, p. 55).

Muitos professores têm medo de distribuir a palavra com seu grupo por alimentar, ainda, de algum modo, a figura do "professor sabe-tudo". E como isso é impossível, acabam restringindo suas possibilidades pedagógicas, promovendo discussões apenas sobre assuntos que entendem. Ao contrário disso, o saber do testemunho já apresenta de antemão que a verdade pode não estar acessível, nem mesmo para quem relata suas vivências:

\begin{abstract}
Nesse sentido, a psicanálise repensa profundamente e renova radicalmente o próprio conceito de testemunho, ao sugerir e ao reconhecer, pela primeira vez na história da cultura, que não é necessário possuir ou ser dono da verdade para testemunhar sobre ela de forma eficiente; que o discurso, enquanto tal, é testemunhal sem o saber e que aquele que fala, constantemente testemunha uma verdade que, apesar disso, continua a lhe escapar. Uma verdade que é, essencialmente, inacessivel para o próprio orador (FELMAN, 2000, p. 27).
\end{abstract}

Nestes tempos em que a verdade não se sustenta mais em um plano metafísico, carecendo passar pela esfera da realidade para ser válida, as históricas imagens do pedagogo, como "aquele que conduz" ou do professor como "aquele que professa" seu saber aos alunos, precisam, no mínimo, ser reconfiguradas. Como uma tentativa de instigar esse processo de reelaboração, é possível pensar que a "arte da condução" do pedagogo pode, agora, estar situada no exercício de discussão, articulando o debate público sobre o passado e sobre o sentido das experiências na cultura. Nessa esteira reconstrutiva, diferentemente de "professar verdades", o professor poderia testemunhar acerca das transformações por que passou a relação com o saber ao longo do tempo, inserindo a crítica como parte do processo de constituição de uma historicidade.

\section{CONSIDERAÇõES FINAIS}

Através das análises reflexivas evidenciadas neste trabalho, percebe-se que há uma necessidade de os saberes docentes serem compreendidos de uma forma mais ampla, indo além do previsto no microcosmo escolar. Isso porque as relações entre o particular e o universal, entre o micro e o macro, são próprias do processo formativo. E silenciarse diante das tragédias e do descaso para com o humano é abrir mão de efetivar o próprio pertencimento no mundo e, consequentemente, assumir os riscos de ser sucumbido por produções acríticas ou de ser diretamente vítima das barbáries cotidianas.

Se, como escreveu Paul Celan, "ninguém testemunha pelas testemunhas", referindo-se ao colapso cultural ocasionado na Segunda Guerra Mundial, o professor também não pode emudecer diante das barbáries já vividas pela humanidade e que, por vezes, ainda a assombram. Especialmente quando discursos xenofóbicos, homofóbicos ou discriminatórios de modo geral encontram ecos na esfera pública. Neste trabalho de compreensão e prevenção, saberes docentes centrados apenas na subjetividade, com tentativas de enumerar competências a serem desenvolvidas, não conseguem expor que a "banalidade do mal" - como diria Hannah Arendt - não é acidental, assim como também não são as 
práticas de brutalidades nas relações pedagógicas entre professores e alunos, notícias que se tornaram corriqueiras nos atuais tempos de convivência na escola.

Tenta-se, então lançar uma reflexão sobre os saberes docentes emergentes em um século pós-traumático, buscando uma possibilidade de justificar o papel do professor no sentido de sua vinculação com o mundo; ideia que o próprio termo "saber" produz. Uma forma de desenvolver esse pertencimento e responsabilização pelo mundo está no saber do testemunho, capaz de valorizar a memória e oportunizar o exercício de alteridade, sem subordinar este trabalho ao desejo de moralizar ou conscientizar o outro.

A discussão no âmbito filosófico-pedagógico possibilita que se agregue aos saberes docentes contribuições que vão além das questões metodológicas do ensino. As raízes da prática pedagógica encontram-se em saberes que compreendem aspectos culturais e históricos. Desse modo, os testemunhos passam a constituir uma ponte interessante de troca de saberes, conciliando o passado e o presente, "por isso os historiadores, cujo ofício é lembrar o que os outros esquecem, tornam-se mais importantes que nunca no fim do segundo milênio" (HOBSBAWM, 1995, p. 13). Parece nítido que, no contemporâneo, o papel do professor, assim como o do historiador, está em estabelecer uma ligação entre presente e passado, vinculando, por meio das práticas pedagógicas, as histórias individuais à história coletiva.

\section{REFERÊNCIAS}

ADORNO, Theodor W. Educação e emancipação. Tradução: Wolfgang Leo Maar. São Paulo: Paz e Terra, 1995.

ADORNO, T. W. A arte é alegre? In: RAMOS-DE-OLIVEIRA, Newton; ZUIN, Antonio Alvaro Soares; PUCCI, Bruno. Teoria crítica, estética e educação. Campinas: Autores Associados, 2001. p. 11-18.

ARENDT, Hannah. Entre o passado e o futuro. Tradução: Mauro W. Barbosa. 6. ed. São Paulo: Perspectiva, 2007.

AMÉRY, Jean. Além do crime e castigo: tentativas de superação. Tradução de Marijane Lisboa. Rio de Janeiro: Contraponto, 2013.

BENJAMIN, Walter. Experiência e pobreza; sobre o conceito da história. In: Magia e técnica, arte e política. Tradução: Sérgio Paulo Rouanet. São Paulo: Brasiliense, 1986, p. 114-119.

BOMBASSARO, Luiz Carlos. As fronteiras da epistemologia: uma introdução ao problema da racionalidade e da historicidade do conhecimento. Petrópolis: Vozes 1992.

BOUFLEUER, José Pedro. O operar pedagógico sob o primado da comunicação: a pedagogia em perspectiva autofundante. In: Reunião Anual da Anped, 30, 2007, Caxambu. Anais... Caxambu: Associação Nacional de Pesquisa e Pós-Graduação em Educação, 2007. [1 CD-ROM].

CELAN, Paul. A arte poética: o meridiano e outros textos. Lisboa: Cotovia, 1996.
CELAN, P. Obras completas. Madrid: Editorial Trotta, 2004.

DE MARCO, Valeria. A literatura de testemunho e a violência de estado. Lua Nova, São Paulo, n. 62, p. 45-68, 2004. Disponível em: <http:/www.scielo.br/pdf/ln/n62/a04n62>. Acesso em: 20 fev. 2015.

FELMAN, Shoshana. Educação e crise ou as vicissitudes do ensinar. In: NESTROVSKI, Arthur; SELIGMANN-SILVA, Márcio (orgs.). Catástrofe e representação: ensaios. São Paulo: Escuta, 2000, p. 13-72.

GADAMER, Hans-Georg. Verdade e método. Tradução: Flávio Paulo Meurer. Petrópolis: Vozes, 1997.

HABERMAS, Jürgen. A constelação pós-nacional: ensaios políticos. São Paulo: Littera Mundi, 2001.

HABERMAS, J. Verdade e justificação. São Paulo: Loyola, 2004.

HERMANN, Nadja. Autocriação e horizonte comum: ensaios sobre educação ético-estética. Ijuí: Unijuí, 2010.

HOBSBAWM, Eric. Era dos extremos: o breve século XX (1914-1921). São Paulo: Companhia das Letras, 1995.

JIMENEZ, Marc. O que é estética? São Leopoldo: Ed. Unisinos, 1999.

LARROSA, Jorge. Notas sobre a experiência e o saber de experiência. Revista Brasileira de Educação, n. 19, p. 20-28, jan./abr. 2002.

MATTÉI, Jean-François. A barbárie interior: ensaio sobre o i-mundo moderno. Tradução: Isabel Maria Loureiro. São Paulo: Editora Unesp, 2002.

PAGNI, Pedro G.; GELAMO, Rodrigo P. (orgs.). Experiência, educação e contemporaneidade. São Paulo: Cultura Acadêmica, 2010.

PERRENOUD, Philippe. A prática reflexiva no ofício do professor: profissionalização e razão pedagógica. Tradução: Cláudia Schilling. Porto Alegre: Artmed, 2002.

LEVI, Primo. É isto um homem? Tradução: Luigi del Re. Rio de Janeiro: Rocco, 1988.

LEVI, P. Os afogados e os sobreviventes. Tradução de Luiz Sérgio Henriques. Rio de Janeiro: Paz e Terra, 1990.

LEVI, P. A trégua. Tradução: Marco Lucchesi. São Paulo, Companhia das Letras, 1997.

RAJCHMAN, Chil. Mais sobre Eu Sou o Último Judeu Treblinka (1942-1943). Tradução de André Telles. Rio de Janeiro: Jorge Zahar, 2010.

RICOEUR, Paul. A memória, a história e o esquecimento. Tradução de Alain François. Campinas: Editora da Unicamp, 2007.

SCHLOSS, Eva. Mais sobre Depois de Auschwitz - o emocionante relato de uma jovem que sobreviveu ao Holocausto. Tradução: Amanda Moura. São Paulo: Universo dos Livros, 2013.

VENEZIA, Shlomo. Sonderkommando: no inferno das câmaras de gás. Tradução: Jorge Bastos. Rio de Janeiro: Objetiva, 2010.

TARDIF, Maurice. Saberes docentes e formação profissional. Petrópolis: Vozes, 2002.

Submetido em: 21/02/2015

Aprovado em: 24/11/2015 